\title{
Egyetemi hallgatók Dark Triad személyiségvonásai és etikai attitűdje közötti lehetséges kapcsolatok
} vizsgálata

\section{Analysing the possible connection between Dark Triad personality traits and ethical attitudes of university students}

\author{
E. BARIZSNÉ HADHÁZI ${ }^{1}$, M. UJHELYI ${ }^{2}$
}

\begin{abstract}
1Debreceni Egyetem, Gazdaságtudományi Kar, Vezetés- és Szervezéstudományi Intézet, Vezetéstudományi Tanszék, barizsne.hadhazi.edit@econ.unideb.hu

2Debreceni Egyetem, Gazdaságtudományi Kar, Vezetés- és Szervezéstudományi Intézet, Vezetéstudományi Tanszék, maria.ujhelyi@econ.unideb.hu
\end{abstract}

Absztrakt. Írásunkban a Dark Triad (Sötét Hármas) személyiségvonások és az etikai attitüdök lehetséges kapcsolatát vizsgáltuk egyetemi hallgatók körében. Mindkét témakör elemzése az érdeklődés központjába került az elmúlt évtizedekben. A kutatók az etikai attitűdök és magatartás hátterében számos tényező hatását vizsgálják. Többek között a személyiség is egy lehetséges befolyásoló tényező. A Dark Triad személyiség a társadalmilag nem kívánatos nárcizmus, machiavellizmus és pszichopátia együttes erôs jelenlétét jelenti. Az ilyen embereket az önimádat, agresszivitás, bűntudat, vagy lelkiismeret hiánya jellemzi, így feltételezésünk szerint kevésbé rendelkeznek etikus attitüdökkel. Kutatásunkban ezt az összefüggést vizsgáltuk a Debreceni Egyetem Természettudományi és Technológiai Kar, valamint a Gazdaságtudományi Kar zömében első éves hallgatói körében végzett kérdőíves felméréssel. A válaszadók kitöltötték a Sötét Hármas mérésére kidolgozott validált „Dirty Dozen” kérdőívet, valamint a Lozier kutatásaiból adaptált kérdőívet, amelyben iskolai szituációkról kellett a válaszadóknak nyilatkozni azok etikus, vagy nem etikus voltáról, illetve az etikátlanság mértékéről. Kutatásunkban arra kerestük a választ, hogy van-e szignifikáns kapcsolat a Sötét Hármas jellemzők erőssége és a szituációk etikai szempontból történő megítélése között. Megvizsgáltuk a férfiak és nők, illetve a két kar hallgatói közötti különbségeket is.

Abstract. In our paper we examined the possible connection between the Dark Triad personality traits and ethical attitudes among university students. The analysis of both topics has become the focus of interest in the past decades. Researchers consider the impact of many factors in the background of ethical attitudes and behavior. Among other things, personality is also a potential factor. The Dark Triad personality means the coexistence of the socially undesirable narcissism, Machiavellianism and psychopathy. Such people are characterized by self-love, aggression, the lack of guilt or conscience, so they are less likely to have ethical attitudes. In our research, this connection was examined by a questionnaire survey conducted among first year students of University of Debrecen Faculty of Natural Sciences and Technology and Faculty of Economics and Business. Respondents completed the validated Dirty Dozen questionnaire which was developed to measure Dark Triad personality and a questionnaire adapted 
from Lozier's research in which respondents were asked to evaluate school situations whether they are ethical or unethical and to what extent they are unethical. In our research, we were looking for significant relationships between the strength of the Dark Triad characteristics and the ethical judgment of situations. We also analyzed the differences between men and women and students of the two faculties.

\section{Bevezetés}

Tanulmányunk célja hogy feltárjuk a vizsgálatunkba bevont egyetemi hallgatók Dark Triad személyiségvonásai és etikai attitűdje közötti lehetséges kapcsolatot. Kutatási ötletünk háttere, hogy számos empirikus elemzés született már egyetemi hallgatói mintán az etika és a személyiség vizsgálatok terén egyaránt. McCabe több írásában [1] [2] [3] [4] a csalás formáit és lehetséges magyarázó változóinak kapcsolatát elemezte. Sims [5] bizonyította, hogy a hallgatói magatartás és a későbbi munkahelyi viselkedés összefügg egymással, ezért ezen a mintán végzett kutatásokból következtetni lehet a következő években munkaerőpiacra lépők etikai magatartására.

A személyiségvonások, még konkrétabban a Dark Triad jellemzők vizsgálatát is gyakran egyetemi hallgatók körében végezték a kutatók [6] [7]. Igazolták, hogy a Dark Triad jellemvonások és a nemkívánatos munkahelyi magatartás között gyenge korrelációs kapcsolat van [8]. A két témakör együttes vizsgálatára példa Furhnam kutatása [9], aki az egyes Dark Triad jellemvonások és az etikátlan magatartás között talált kapcsolatot.

Saját kutatásaink is születtek már a témával kapcsolatban. Külön-külön is vizsgáltuk a hallgatók Dark Triad személyiségvonásait [10], csalással kapcsolatos magatartását [11], illetve egy kisebb adatbázison összehasonlítottuk a hallgatók Dirty Dozen kérdőívvel mért eredményeit valamint Ludlum kérdőívére adott válaszok közötti kapcsolatot [12] [13] [14].

Ezt a kutatási témát bővítjük tovább jelenlegi tanulmányunkban, ahol a Debreceni Egyetem Természettudományi és Technológiai Kar és a Gazdaságtudományi Kar többségében első éves hallgatói körében végzett kutatásunkat mutatjuk be.

\section{Szakirodalmi áttekintés}

Az egyetemi hallgatók etikai attitûdjével kapcsolatos munkákkal mind nemzetközi, mind pedig hazai kutatásokban találkozhatunk. A témakör egyik legismertebb kutatói McCabe és kutatócsoportja, akik már az 1960-as évek óta több munkájukban foglalkoztak egyetemi hallgatók csalással kapcsolatos értékrendjével, magatartásával. Kutatásaik során megállapították, hogy a hallgatók részvétele a csalásban növekvő mértékű a vizsgált 30 éves periódust tekintve [3], a nemek szerinti megoszlást illetően pedig magasabb a csalásban résztvevő nők aránya [1]. A csalást befolyásoló tényezők között rámutattak arra, hogy a társak elfogadó szemlélete, és az, hogy a hallgató látja társait csalni növeli a csalásban való részvételt [2]. Elemzéseik felhívták a figyelmet a csoport befolyásoló erejére is, számszerűen is bebizonyosodott, hogy ennek hatása kétszer erősebb, mint ha fenyegetést helyezünk kilátásba büntetésként [2]. 2001-ben megjelent tanulmányukban azt is vizsgálták, hogy az egyetemek etikai kódexe milyen hatással van a hallgatók csalással összefüggő magatartására [4]. Ezzel 
kapcsolatban felhívták a figyelmet arra, hogy önmagában az etikai kódexek elkészítése nem elegendő, ezeket meg kell ismertetni hallgatókkal és oktatókkal egyaránt, csak így érhető el vele a kívánt hatás.

Szintén felsőoktatásban tanulók etikus magatartását vizsgálta az a kutatássorozat, amely Ludlum és munkatársai nevéhez kötődik [15]. Szerzőtársaival 2009-ben, majd pedig 2015-ben ismételten azt vizsgálták, hogyan vélekednek egyetemi hallgatóik 20 etikátlannak ítélt munkahelyi szituációról. A diákok a következő helyzetekről nyilatkozták azt, hogy szerintük az a felsoroltak közül a legetikátlanabb: megvádolni egy ártatlan kollégát azzal, amivel minket vádolnak; nyilvánosságra hozni a titkos információkat; valaki más munkájáért learatni a babérokat, illetve jelentést hamisítani [13] [14].

Ludlum és kutatócsoportja munkája nyomán mi is végeztünk felméréseket a Debreceni Egyetem Gazdaságtudományi Karának hallgatói körében [12]. Bár a 61 fốt érintő kutatásunk reprezentatívnak nem volt mondható, s általánosítható következtetéseket nem vonhatunk le eredményeinkből, mégis hasznos lehet abból a szempontból, hogy megalapozzon további felméréseket, s felhívja a figyelmet a téma fontosságára. A Ludlum és társai által is vizsgált munkahelyi magatartásformák közül saját hallgatóink kilencet értékeltek különösen etikátlannak: a titkos információk nyilvánosságra hozatalát, a minket ért vádakkal mások megvádolását, eltulajdonítani valamit a cég eszközeiből, más munkájának babérjait learatni, a jelentések meghamisítását, a munka közbeni alvást, a céges szabályzatok megszegésének engedélyezését, a számlák 10\%-nál nagyobb értékű növelését és a templomban történő alvást. A kapott eredmények alapján diákjaink szigorúbbnak bizonyultak amerikai és orosz társaiknál, azonban ez nem jelenti egyben azt is, hogy ők maguk etikusabban cselekednének, hiszen itt mindössze arról van szó, hogy egy adott szituációt hogyan ítéltek meg [11].

Jelen kutatásunk egyik része egyetemi hallgatók etikai attitűdjeit szándékozik felmérni, ennek során Lozier [16] munkája alapján állítottuk össze kérdőívünknek ezen részét. Lozier tanulmányában 20 iskolai szituáció értékelésére kérte meg válaszadóit: elsőként arra, hogy szerintük a leírt helyzet csalás-e vagy sem, másodsorban pedig arra, hogy amennyiben a leírt szituációban szereplő tevékenységet csalásnak tartják, akkor értékeljék annak komolyságát egy 5 fokozatú Likert skálán. Saját munkánkban az eredeti kérdőívet lerövidítettük, csupán 10 iskolai cselekedetről kellett a megkérdezetteknek nyilatkozniuk, törekedtünk arra is, hogy a hazai körülményekhez hasonló magatartásformákat jelenítsünk meg, amelyet hallgatóink is ismerhetnek. Egy korábbi kutatásunkban [17] egy kisebb mintán teszteltük a kérdőívet, ennek során a következőket fogalmaztuk meg: diákjainkról elmondhatjuk, hogy a csalást és a plágiumot felismerték, de amerikai társaikhoz képest elnézőbbek azok megítélése során.

Empirikus kutatásokban a Dark Triad személyiség elemzésénél is gyakran szerepelnek egyetemi hallgatók vizsgálati alanyokként [6], [7]. Ez a modell három társadalmilag nemkívánatosnak ítélt személyiségvonást foglal magába a nárcizmust, machiavellizmust és a pszichopátiát [18].

Az Amerikai Pszichiátriai Egyesület által 2000-ben megfogalmazott „Mentális zavarok diagnosztikai és statisztikai kézikönyve" szerint a nárcizmus szélesen értelmezve a saját nagyszerűség és fontosság érzése. A narcisztikus személyek korlátlan sikerekről fantáziálnak, különlegesnek, egyedinek hiszik magukat, csodálatot várnak másoktól, a kapcsolataikban kizsákmányolók, hiányzik belőlük az empátia, 
arrogánsak és önteltek [19]. Az egyének különböznek egymástól narcisztikus jellemzőiket illetően és a normális populációban is mérhetőek ezek a jellemvonások [20].

Az erősen machiavellista személyek jellemzője, hogy saját céljuk elérése érdekében manipulálnak másokat. Hiányoznak belőlük az érzések az interperszonális kapcsolatokban, tárgyaknak, vagy eszközöknek tekintenek másokat. Nem foglalkoznak a konvencionális morállal, haszonelvúek. A jelenben élnek, el akarják érni céljukat, nem törődnek annak hosszú-távú következményeivel [21].

A Dark Triad harmadik személyiség típusa a pszichopátia. Hasonlóan a nárcizmushoz eredetileg mentális zavarnak tekintették, de Levenson és társai [22] szerint a normális népességben is megjelenő személyiségvonásról van szó. Az emberekkel és a társadalmi szabályozó mechanizmusokkal való törődés hiánya, lobbanékonyság, bűntudat és lelkiismeret hiány jellemzi az erősen pszichopatákat, amikor tetteikkel másoknak bajt okoznak. A személyek közötti kapcsolatokban gyakran sikeresen befolyásolják a róluk alkotott benyomást, bőbeszédűek és karizmatikusak. Érzelmileg sekélyesek, gyakran parazita életmódot folytatnak [23].

Annak ellenére, hogy általánosan nemkívánatos jellemzőknek gondoljuk e három személyiségvonást, mégis számos népszerű, kedvelt film főhős (Dr. Hause, James Bond), vagy TV sztár (Stephen Colbert) igen erős Dark Triad személyiség vonásokkal rendelkezik [24]. Üzleti környezetben is sikeresek lehetnek azok, akikre jellemző e három személyiségvonás, különösen, ha érzelemszegény magatartást, vagy racionális tevékenységet igényel a munka [25].

A kutatásokban megjelennek a Dark Triad személyiségvonások és az etikátlan, nemkívánatos munkahelyi magatartás kapcsolatát bizonyító eredmények. Jonason és Webster [6] egyetemi hallgatók körében végzett kutatásukban azt állapították meg, hogy az erősen Dark Triad személyiségű emberek a társas befolyásolás változatos eszközeit alkalmazzák, s ennek segítségével sikeresen elkerülik csalásuk (manipulálásuk) lelepleződést. Boyle és társai [25], valamint Cohen [8] a Dark Triad és a nemkívánatos munkahelyi magatartás (Counterproductive Workplace Behaviour) között találtak bizonyos mértékű együtt járást. Judge és társai [19] a munkahelyi devianciával kapcsolatosan foglalták össze az eddigi kutatási eredményeket. Furnham és társai [9] a Dark Triad jellemvonások és a csalás kapcsolatát bizonyító, egyetemi hallgatók körében végzett kutatások eredményeit összegezték. A pszichopátia előre jelezte a vizsgamásolást, a machiavellizmus pedig a plagizálást. A kutatásokban résztvevő erősen pszichopata, vagy machiavellista hallgatók között voltak, akik kihasználva a kiskapukat extra pontokat követeltek, amiért nem dolgoztak meg.

Jelen kutatásunk előzményeként a Debreceni Egyetem Gazdaságtudományi Karának hallgatói körében, végeztünk felmérést a Dark Triad személyiségvonások megjelenésének gyakoriságára vonatkozóan [10], illetve ugyanezen a mintán elemeztük a Dark Triad személyiség és etikusság kapcsolatát is [12]. Gyenge ellentétes irányú együtt mozgást találtunk a hallgatók machiavellista és narcisztikus vonásai, valamint etikai attitűdjei között. 


\section{Adatok és módszer}

Empirikus vizsgálatunkban a Dirty Dozen kérdőív [26] magyarra fordított változatával értékeltük a válaszadók személyiségvonásait. A 12 kérdésből 4-4 méri a nárcizmust, a Machiavellizmust és a pszichopátiát. 7 fokozatú Likert skálán kellett bejelölni, hogy mennyire jellemzőek a válaszadókra a felsorolt megállapítások. Akkor tekintünk „Sötét Hármas” tagnak egy válaszadót, ha mindhárom jellemzőben legalább 15 pontot ér el. A válaszadók etikai attitűdjét a Lozier [16] által használt kérdőív magyarra fordított adaptált és egyszerűsített változatával mértük. Eredetileg húsz szituációból kutatásunkban 10-et kérdeztünk meg. Nyilatkozni kellett a válaszadóknak, hogy csalásnak tartják-e a leírt helyzetet, vagy nem, ha véleményük szerint csalás, akkor annak mértékét is meg kellett jelölniük egy 5 fokozatú Likert skálán. A kérdőív néhány demográfiai háttérre vonatkozó adatot is tartalmazott.

Az adatgyűjtést 2017-ben végeztük. Tantermi órák keretében kértük meg a hallgatókat a kérdőív kitöltésére. A válaszadás önkéntes és anonim volt. 347 kérdőív volt értékelhető. A válaszadók 33,4\%-a férfi, 66,6\%-a nő. 228 fő (67\%) a Gazdaságtudományi Kar, 112 fő (33\%) a Természettudományi és Technológiai Kar hallgatója.

\section{Eredmények}

A kutatásban résztvett hallgatók Dirty Dozen kérdőív segítségével számított személyiség jellemzői a következők: A machiavellizmus átlag pontja 11,46, szórása 5,06; nárcizmus átlaga 13,61, szórása 4,93; pszichopátia átlaga 9,36, szórása 4,25. Az összpontszám átlaga 34,43 (szórása 11,61), ami kicsivel alatta marad a nemzetközi mintában mért 36 pontos értéknek [23]. A teljes mintában 93 fő (26,8\%) erősen Machiavellista (legalább 15 pontot ért el), 150 fő (43,2\%) narcisztikus, és 37 fő $(10,7 \%)$ erősen pszichopata. Összesen 57 -en $(16,4 \%)$ értek el legalább 45 pontot, ami a Dark Triad tagság feltétele. Egy szigorúbb kritérium szerint mind a három jellemzőben legalább 15 pontot elérőket sorolják ide. Ilyen hallgatókból 20 fő (5,76\%) van a mintában.

A válaszadó hallgatók etikai értékrendjére vonatkozó számszerűsíthető eredményeinket foglalja össze az 1. táblázat. Láthatjuk, hogy a diákok ezen megkérdezés során is felismerték azokat a szituációkat, amelyek csalásként értelmezhetőek, a 10 szituációból ugyanis 8 esetben legalább 90\%-uk jelölte meg csalásként az adott tevékenységet. Azt azonban, hogy mennyire komoly csalás az adott magatartás már csak közepes szigorral jelezték vissza: ezt az átlagértékek szerint 3,1 és 3,5 közötti átlagértékekkel jellemezték. Az a két szituáció pedig, amit nem minősítettek csalásként még 2,5 átlagértéket sem kapott (még azon hallgatók körében sem, akik szerint ez mégiscsak csalás). Lozier [16] vizsgálati eredményéhez hasonlítva ezeket az eredményeket azt mondhatjuk, hogy hallgatóink nagyobb arányban jelölték meg csalásként valamennyi helytelen magatartásformát, ugyanakkor kevésbé voltak szigorúak amerikai társaikhoz képest. A debreceni diákok egyik helyzetet sem értékelték legalább 4-es átlagértékkel, míg az amerikai diákok 6 esetben is így tettek [9]. Megfogalmazhatjuk tehát, hogy diákjaink szigorúbbak annak megítélésében, hogy egy cselekedet csalás-e vagy sem, de annak komolyságának megítélésében már engedékenyebbek. 


\begin{tabular}{|cl|c|c|}
\hline Szituáció sorszáma, rövid leírása & $\begin{array}{c}\text { Azon hallgatók aránya, } \\
\text { akik csalásnak } \\
\text { értékelték (\%) }\end{array}$ & $\begin{array}{c}\text { Átlagosan milyen } \\
\text { mértékben értékelték } \\
\text { csalásnak (szórás) }\end{array}$ \\
\hline 1. & Plágium & 95 & $3,5(1,2)$ \\
\hline $\begin{array}{l}\text { 2. } \\
\text { mgy társ beszédének szó szerinti }\end{array}$ & 91 & $3,4(1,3)$ \\
\hline 3. & Beadandának beadása & 91 & $3,4(1,3)$ \\
\hline 4. & $\begin{array}{l}\text { Facebook-rósa mál másolt eredmények } \\
\text { benyújtása }\end{array}$ & 92 & $3,4(1,2)$ \\
\hline 5. & Dolgozatírás közbeni lesés & 85 & $3,3(1,0)$ \\
\hline 6. & Neten megtalált tesztmegoldás & 93 & $3,2(1,3)$ \\
\hline 7. & Telefonos csalás vizsga közben & 94 & $3,1(1,2)$ \\
\hline 8. & Torzított munkaidő-nyilvántartás & 91 & $3,1(1,2)$ \\
\hline 9. & Önálló gondolatok nélkül elkészített & & $2,4(1,3)$ \\
\hline beadandó & Közös munka egyéni munka helyett & 56 & $2,3(1,2)$ \\
\hline
\end{tabular}

1. táblázat: Az egyes szituációk értékelése a hallgatók szerint

A következőkben tekintsük át, hogy milyen összefüggéseket találtunk a Dark Triad személyiségvonások és a hallgatók etikai attitűdjei között. Első vizsgálati szempontunk minden esetben az, hogy milyen arányban értékelték az egyes tevékenységeket csalásként a válaszadók, második vizsgálati szempontunk pedig az, hogy az így kialakult két csoport Dark Triad személyiségvonásait tükröző átlagokban van-e szignifikáns különbség.

A neten talált tesztmegoldás felhasználásával kapcsolatban a diákok jelentős része úgy nyilatkozott, hogy az bizony csalás (2. táblázat). Ha az így kialakult két csoport véleményét összevetjük, akkor azt mondhatjuk, hogy eredményeink szerint szignifikáns különbség van a két csoport átlaga között, mindhárom Dark Triad vonás tekintetében: a számok azt mutatják, hogy azokra jellemző kevésbé a sötét hármas személyiség, akik csalásként értékelték ezt a magatartást (az ő átlagértékük mindhárom tulajdonság esetében alacsonyabb).

\begin{tabular}{|l|c|l|c|c|c|}
\hline & $\begin{array}{l}\text { Válaszadók } \\
\text { száma }\end{array}$ & $\begin{array}{l}\text { Mennyire } \\
\text { súlyos } \\
\text { csalás? }\end{array}$ & $\begin{array}{l}\text { Machiavellizmus } \\
\text { átlag (szórás) }\end{array}$ & $\begin{array}{l}\text { Nárcizmus } \\
\text { átlag (szórás) }\end{array}$ & $\begin{array}{l}\text { Pszichopata } \\
\text { átlag (szórás) }\end{array}$ \\
\hline Nem csalás & 23 & - & $13,96(5,76)$ & $15,74(4,95)$ & $11,39(5,66)$ \\
\hline Csalás & 324 & $3,16(1,25)$ & $11,28(4,97)$ & $13,46(4,90)$ & $9,22(4,10)$ \\
\hline $\begin{array}{l}\text { Nem } \\
\text { válaszolt }\end{array}$ & 0 & - & - & - & - \\
\hline
\end{tabular}

2. táblázat: A neten talált tesztmegoldás sajátként történó benyújtása

Annak megítélésében, hogy közösen dolgozunk egy feladaton annak ellenére, hogy a tanár egyéni feladatmegoldást kért tőlünk, már megosztottabbak voltak diákjaink (3. táblázat): mindössze 56\%-uk szerint jelent ez csalást. Itt a személyiség és az etikai attitűd között a két csoportot alapul véve nem találtunk szignifikáns különbséget. 


\begin{tabular}{|l|c|c|c|c|c|}
\hline & $\begin{array}{l}\text { Válaszadók } \\
\text { száma }\end{array}$ & $\begin{array}{l}\text { Mennyire } \\
\text { súlyos } \\
\text { csalás? }\end{array}$ & $\begin{array}{l}\text { Machiavellizmus } \\
\text { átlag (szórás) }\end{array}$ & $\begin{array}{l}\text { Nárcizmus } \\
\text { átlag (szórás) }\end{array}$ & $\begin{array}{l}\text { Pszichopata } \\
\text { átlag (szórás) }\end{array}$ \\
\hline Nem csalás & 144 & - & $12,08(5,27)$ & $13,91(5,18)$ & $9,58(4,85)$ \\
\hline Csalás & 203 & $2,33(1,19)$ & $11,02(4,87)$ & $13,40(4,76)$ & $9,20(3,76)$ \\
\hline $\begin{array}{l}\text { Nem } \\
\text { válaszolt }\end{array}$ & 0 & - & - & - & - \\
\hline
\end{tabular}

3. táblázat: Közös munka benyújtása egyéni munka helyett

A plágiumot a hallgatók nagyon kevés kivétellel csalásként jelölték meg (4. táblázat), s e tekintetben voltak a legszigorúbbak is (3,47-es átlagértékkel). Ezen két csoport személyiségét tekintve csak a machiavellisztikus és a nárcisztikus vonásukban találtunk szignifikáns különbséget.

\begin{tabular}{|l|c|c|c|c|c|}
\hline & $\begin{array}{l}\text { Válaszadók } \\
\text { száma }\end{array}$ & $\begin{array}{l}\text { Mennyire } \\
\text { súlyos csalás? }\end{array}$ & $\begin{array}{l}\text { Machiavellizmus } \\
\text { átlag (szórás) }\end{array}$ & $\begin{array}{l}\text { Nárcizmus } \\
\text { átlag } \\
\text { (szórás) }\end{array}$ & $\begin{array}{l}\text { Pszichopata } \\
\text { átlag (szórás) }\end{array}$ \\
\hline Nem csalás & 19 & - & $14,57(6,08)$ & $16,16(5,63)$ & $9,26(4,75)$ \\
\hline Csalás & 328 & $3,47(1,24)$ & $11,28(4,95)$ & $13,47(4,86)$ & $9,37(4,22)$ \\
\hline $\begin{array}{l}\text { Nem } \\
\text { válaszolt }\end{array}$ & 0 & - & - & - & - \\
\hline
\end{tabular}

4. táblázat: A plágium értékelése a hallgatók szerint

A hallgatók döntő többsége (91\%-uk) úgy vélekedik, hogy egy társuk munkáját változtatás nélkül saját nevük alatt beadni szintén csalás (5. táblázat). A személyiség és az etikai attitűd kapcsolatát vizsgálva azonban csak annyit tudunk megállapítani, hogy a vizsgált két csoport között csak a nárcisztikus jellemvonás esetében van szignifikáns különbség.

\begin{tabular}{|l|c|c|c|c|c|}
\hline & $\begin{array}{l}\text { Válaszadók } \\
\text { száma }\end{array}$ & $\begin{array}{l}\text { Mennyire } \\
\text { súlyos } \\
\text { csalás? }\end{array}$ & $\begin{array}{l}\text { Machiavellizmus } \\
\text { átlag (szórás) }\end{array}$ & $\begin{array}{l}\text { Nárcizmus } \\
\text { átlag (szórás) }\end{array}$ & $\begin{array}{l}\text { Pszichopata } \\
\text { átlag (szórás) }\end{array}$ \\
\hline Nem csalás & 31 & - & $14,03(5,39)$ & $14,97(4,64)$ & $10,32(4,40)$ \\
\hline Csalás & 316 & $3,35(1,28)$ & $11,20(4,96)$ & $13,48(4,95)$ & $9,27(4,23)$ \\
\hline $\begin{array}{l}\text { Nem } \\
\text { válaszolt }\end{array}$ & 0 & - & - & & - \\
\hline
\end{tabular}

5. táblázat: Egy társ munkáját változtatás nélkül sajátként benyújtani

A saját, önálló gondolatok nélkül beadott („összeollózott”) házi dolgozat benyújtása a hallgatók közel 40\%-a szerint nem csalás (6. táblázat), és akik csalásként értékelték ezt a cselekedetet, ők sem gondolják úgy, hogy ez nagyon komoly etikátlanság lenne (2,42 átlagérték). A két csoport között személyiségben nem mutatkozott szignifikáns különbség.

\begin{tabular}{|l|l|l|l|l|l|}
\hline & $\begin{array}{l}\text { Válaszadók } \\
\text { száma }\end{array}$ & $\begin{array}{l}\text { Mennyire } \\
\text { súlyos } \\
\text { csalás? }\end{array}$ & $\begin{array}{l}\text { Machiavellizmus } \\
\text { átlag (szórás) }\end{array}$ & $\begin{array}{l}\text { Nárcizmus } \\
\text { átlag (szórás) }\end{array}$ & $\begin{array}{l}\text { Pszichopata } \\
\text { átlag (szórás) }\end{array}$ \\
\hline Nem csalás & 216 & - & $11,49(5,07)$ & $13,63(4,92)$ & $9,38(4,39)$ \\
\hline Csalás & 131 & $2,42(1,34)$ & $11,40(5,06)$ & $13,60(4,98)$ & $9,34(4,00)$ \\
\hline $\begin{array}{l}\text { Nem } \\
\text { válaszolt }\end{array}$ & 0 & - & - & - & - \\
\hline
\end{tabular}

6. táblázat: Önálló gondolatok nélkül benyújtott házi dolgozat megítélése 
A válaszadó hallgatók mindössze 9\%-a nem ítéli el azt, ha valaki az interneten vásárol beadandó dolgozatot egy tantárgy teljesítése érdekében, míg a többiek egyöntetúen elítélik ezt a tettet (7. táblázat). Elmondhatjuk azt is, hogy ezen két csoport között sziginfikáns különbségeket találunk mindhárom Dark Triad személyiségvonást illetően: akik kevésbé jellemezhetőek ezen negatív tulajdonságokkal, ők bizony többnyire elítélték ezt a magatartást.

\begin{tabular}{|l|l|l|l|l|l|}
\hline & $\begin{array}{l}\text { Válaszadók } \\
\text { száma }\end{array}$ & $\begin{array}{l}\text { Mennyire } \\
\text { súlyos } \\
\text { csalás? }\end{array}$ & $\begin{array}{l}\text { Machiavellizmus } \\
\text { átlag (szórás) }\end{array}$ & $\begin{array}{l}\text { Nárcizmus } \\
\text { átlag (szórás) }\end{array}$ & $\begin{array}{l}\text { Pszichopata } \\
\text { átlag (szórás) }\end{array}$ \\
\hline Nem csalás & 31 & & $15,99(5,75)$ & $16,48(5,63)$ & $12,87(6,93)$ \\
\hline Csalás & 315 & $3,44(1,28)$ & $11,03(4,77)$ & $13,31(4,77)$ & $9,03(3,73)$ \\
\hline $\begin{array}{l}\text { Nem } \\
\text { válaszolt }\end{array}$ & 1 & - & - & - & - \\
\hline
\end{tabular}

7. táblázat: Beadandó dolgozatot vásárolni a neten

\begin{tabular}{|l|l|l|l|l|l|}
\hline & $\begin{array}{l}\text { Válaszadók } \\
\text { száma }\end{array}$ & $\begin{array}{l}\text { Mennyire } \\
\text { súlyos } \\
\text { csalás? }\end{array}$ & $\begin{array}{l}\text { Machiavellizmus } \\
\text { átlag (szórás) }\end{array}$ & $\begin{array}{l}\text { Nárcizmus } \\
\text { átlag (szórás) }\end{array}$ & $\begin{array}{l}\text { Pszichopata } \\
\text { átlag (szórás) }\end{array}$ \\
\hline Nem csalás & 27 & - & $14,78(6,14)$ & $15,74(6,16)$ & $11,93(6,73)$ \\
\hline Csalás & 320 & $3,35(1,20)$ & $11,18(4,86)$ & $13,43(4,79)$ & $9,14(3,90)$ \\
\hline $\begin{array}{l}\text { Nem } \\
\text { válaszolt }\end{array}$ & 0 & - & - & - & - \\
\hline
\end{tabular}

8. táblázat: Facebook-ra kiposztolt dolgozat megoldásait lemásolni

A hallgatóknak értékelniük kellett egy olyan szituációt is, amelyben egy diák büszke saját vizsgadolgozatára, lefényképezve azt kiposztolja a facebookra, alkalmat adva ezzel arra a szituáció szereplőjének, hogy lemásolja azokat. Ezt válaszadóink 92\%-a jelölte meg csalásként (8. táblázat). Megállapíthatjuk azt is, hogy döntően azok nyilatkoztak így, akik kevésbé jellemezhetőek a Dark Triad vonás valamelyikével, hiszen valamennyi negatív tulajdonság átlaga között szignifikáns különbséget találtunk.

A megkérdezett hallgatók nem voltak ennyire szigorúak azonban annak megítélésében, hogy dolgozatírás közben lesni csalásnak számít-e (9. táblázat), ezt mindössze 85\%-uk gondolja így, javarészt azok, akik kevésbé hordozzák magukban a machiavellizmus és a pszichopata jellemvonásokat (e két esetben volt szignifikáns különbség az átlagértékek között).

\begin{tabular}{|l|l|l|l|l|l|}
\hline & $\begin{array}{l}\text { Válaszadók } \\
\text { száma }\end{array}$ & $\begin{array}{l}\text { Mennyire } \\
\text { súlyos } \\
\text { csalás? }\end{array}$ & $\begin{array}{l}\text { Machiavellizmus } \\
\text { átlag (szórás) }\end{array}$ & $\begin{array}{l}\text { Nárcizmus } \\
\text { átlag (szórás) }\end{array}$ & $\begin{array}{l}\text { Pszichopata } \\
\text { átlag (szórás) }\end{array}$ \\
\hline Nem csalás & 53 & - & $13,77(6,08)$ & $14,45(5,86)$ & $10,74(6,08)$ \\
\hline Csalás & 294 & $3,32(1,01)$ & $11,04(4,74)$ & $13,46(4,75)$ & $9,11(3,78)$ \\
\hline $\begin{array}{l}\text { Nem } \\
\text { válaszolt }\end{array}$ & 0 & - & - & - & - \\
\hline
\end{tabular}

9. táblázat: Dolgozatírás közben lesni egy másik vizsgázó válaszairól

Hallgatóink mindössze 5\%-a szerint nem számít csalásnak az, ha vizsga közben telefonon segítséget kérnek (10. táblázat), a többiek ezt egyértelműen etikátlannak tartják. A személyiség sötét hármasát figyelembe véve kijelenthetjük, hogy a kevésbé machiavellisztikus és a nárcisztikus diákok ítélték el inkább ezt a magatartást (esetükben volt a két csoport átlaga között szignifikáns különbség). 


\begin{tabular}{|l|l|l|l|l|l|}
\hline & $\begin{array}{l}\text { Válaszadók } \\
\text { száma }\end{array}$ & $\begin{array}{l}\text { Mennyire } \\
\text { súlyos } \\
\text { csalás? }\end{array}$ & $\begin{array}{l}\text { Machiavellizmus } \\
\text { átlag (szórás) }\end{array}$ & $\begin{array}{l}\text { Nárcizmus } \\
\text { átlag (szórás) }\end{array}$ & $\begin{array}{l}\text { Pszichopata } \\
\text { átlag (szórás) }\end{array}$ \\
\hline Nem csalás & 19 & - & $14,63(6,7)$ & $16,16(6,59)$ & $10,90(6,05)$ \\
\hline Csalás & 327 & $3,11(1,16)$ & $11,28(4,90)$ & $13,47(4,80)$ & $9,28(4,12)$ \\
\hline $\begin{array}{l}\text { Nem } \\
\text { válaszolt }\end{array}$ & 1 & - & - & - & - \\
\hline
\end{tabular}

10. táblázat: Telefonon segítséget kérni vizsga közben

A munkaidő-nyilvántartást torzítani saját érdekünkben a hallgatók 91\%-a szerint csalásként értékelhető (11. táblázat), az ötfokozatú Likert skálán ezt 3,13 átlagértékkel jelölték. Az ezek alapján kialakított két csoportról elmondhatjuk, hogy a machivellisztikus és a pszichopatikus tulajdonságok megléte a szigorúbb értékítélet felé fejtette ki hatását.

\begin{tabular}{|l|l|l|l|l|l|}
\hline & $\begin{array}{l}\text { Válaszadók } \\
\text { száma }\end{array}$ & $\begin{array}{l}\text { Mennyire } \\
\text { súlyos } \\
\text { csalás? }\end{array}$ & $\begin{array}{l}\text { Machiavellizmus } \\
\text { átlag (szórás) }\end{array}$ & $\begin{array}{l}\text { Nárcizmus } \\
\text { átlag (szórás) }\end{array}$ & $\begin{array}{l}\text { Pszichopata } \\
\text { átlag (szórás) }\end{array}$ \\
\hline Nem csalás & 31 & - & $14,10(6,19)$ & $13,80(5,72)$ & $11,61(6,98)$ \\
\hline Csalás & 315 & $3,13(1,24)$ & $11,21(4,87)$ & $13,60(4,87))$ & $9,15(3,83)$ \\
\hline $\begin{array}{l}\text { Nem } \\
\text { válaszolt }\end{array}$ & 1 & - & - & - & - \\
\hline
\end{tabular}

11. táblázat: Munkaidô-nyilvántartás torzítása saját érdekünkben

A fenti számításokon túl végeztünk korrelációs elemzéseket is, amelynek során arra kerestük a választ, hogy van-e együttjárás bizonyos személyiségvonások és a különböző csalással kapcsolatos szituációk komolyságának megítélése között. Elmondhatjuk, hogy a vizsgált mintán e tekintetben csak nagyon gyenge korrelációs együtthatókat találtunk, a Pearson-féle korrelációs együttható értéke e két változó között sehol sem érte el a 0,2 értéket sem.

A Dark Triad vonások közötti együttjárás esetében azonban már közepes szintű korrelációt találtunk: a machiavellisztikus és a nárcisztikus tulajdonság között ez az érték 0,535 (1\%-os szignifikancia szint mellett), a machiavellisztkus és a pszichopatikus jellemvonás között $r=0,567$ (1\%-os szignifikancia szint mellett), végül a nárcisztikus és a pszichopatikus tulajdonság között pedig r=0,375 (1\%-osz szignifikancia szint mellett).

A csalással kapcsolatos szituációk értékelése alapján számos esetben találunk közepes szintű korrelációt, de mindössze egyetlen esetben erőset: a plágium komolyságának megítélése együtt jár annak megítélésével, hogy mennyire komoly csalás egy társuk korábbi munkáját változtatás nélkül benyújtani ( $r=0,639$ 1\%-os szignifikancia szint mellett).

A rendelkezésünkre álló mintán megvizsgáltuk a nem és a kar szerinti hovatartozás alapján fennálló szignifikáns különbségeket is (független kétmintás t-teszt segítségével, 5 \%-os szignifikancia szint mellett). Az eredmények alapján elmondhatjuk, hogy a válaszadó hallgatók neme szerint a machiavellisztikus és a pszichopatikus jellemvonás tekintetében mutatkoztak szignifikáns különbségek, mégpedig mindkét esetben a férfiak átlagértéke volt magasabb. A machiavellisztikus tulajdonság esetében az átlagértékük 12,99 (szórás 5,1) a nők 10,72 (szórás 4,9) értékével szemben, míg a pszichopátia esetében a férfiak átlaga 10,9 (szórás 4,7), a nőké pedig 8,6 (szórás 3,8). Ezen minta 
alapján tehát a vizsgált férfi hallgatók körében erősebben jelennek meg a fenti negatív/Dark Triad sajátosságok.

Ugyanezt megvizsgáltuk Karok szerinti bontásban is: elkülönítettük a Gazdaságtudományi Kar és a Természettudományi és Technológiai Kar hallgatói csoportját, de ugyanezen feltételek mellett itt szignifikáns különbségeket nem találtunk.

Nem találtunk szignifikáns különbséget sem a nemek, sem pedig a kar szerinti bontásban atekintetben sem, hogy a megjelölt szituációt mennyire találták etikusnak vagy etikátlannak.

\section{Zárszóként}

Összefoglalva kutatási eredményeinket megállapíthatjuk, hogy a mintában szereplő hallgatók túlnyomó többsége felismeri az etikátlan iskolai magatartásformákat, de csak közepes mértékben ítélik meg azt komoly csalásként. Körülbelül 16\%-a a megkérdezett hallgatóknak a Dark Triad tagság jegyeivel írható le. A férfiakra magasabb arányban jellemző a macihavellizmus és a pszichopátia. Az egyes Dark Triad jellemvonások egymást is erősítik. Három etikátlan iskolai magatartásforma esetében bebizonyosodott, hogy az erős Dark Triad jellemvonások megléte esetén kevésbé etikusak a válaszadók. Nem találtunk szignifikáns különbségeket a két kar válaszadói között.

\section{Hivatkozások}

[1] D. L McCabe - W. J. Bowers (1996) The relationship between student cheating and college fraternity or sorority membership. NASPA Journal, 33 (4) pp. 280-291.

[2] D. L. McCabe - L. K. Trevino (1993) Academic Dishonesty: Honour Codes and Other Contextual Influences. The Journal of Higher Education, 64 (5) pp. 522-538.

[3] D. L. McCabe - L. K. Trevino (1996) TrevinoWhat We Know about Cheating in Colleg. Change, 28 (1) pp. 28-33.

[4] D. L. McCabe - L. K. Trevino - K. D. Butterfield (2001) Cheating in academic institutions: A decade of research. Ethics \& Behavior, 11 (3) pp. 219-232.

[5] R. L. Sims (1993) The Relationship Between Academic Dishonesty and Unethical Business Practices. Journal of Education for Business, 68 (4) pp. 207-211

[6] P. K. Jonason - G. D. Webster (2012) A protean approach to social influence: Dark Triad personalities and social influence tactics. Personality and Individual Differences, 52 (4) pp. 521526.

[7] E. Jauk - H. H. Freudenthaler - A. C. Neubauer (2016) The Dark Triad and trait vs. ability emotional intelligence: Emotional darkness differs betweek women and men. Journal of Individual Differences, 37 pp. 112-118.

[8] Cohen (2016) Are they among us? A conceptual framework of the relationship between the dark triad personality and counterproductive work behaviors (CWBS). Human Resource Management Review, 26 pp. 69-85

[9] Furnham - S.C. Richards - D. L. Paulhus (2013) The Dark Triad of Personality: A 10 Year Review. Social and Personality Psychology Compass, 7 (3) pp. 199-216. 
[10] M. Ujhelyi (2017) A sötét hármas megjelenése egyetemi hallgatók körében. International Journal of Engineering and Management Sciences/Műszaki és Menedzsment Tudományi Közlemények, 2 (4) pp. 579-588.

[11] E. Barizsné Hadházi - Zs. Kiss (2016) Hallgatók etikai attitúdvizsgálata. International Journal of Engineering and Management Sciences/Műszaki és Menedzsment Tudományi Közlemények, 1 (1) megtekinthető: http://ijems.lib.unideb.hu/cikk/cikk/57695b9692ac9

[12] E. Barizsné Hadházi - M. Ujhelyi (2017) University Students' Dark Triad Traits and Ethical Attitudes. Annals of the University of Oradea Economic Science, 26 (1) pp. 739-748.

[13] M. Ludlum - S. Moskaloinov - V. Ramachandran (2013) Examining Ethical Behaviors by Business Studenst. American International Journal of Contemporary Research, 3 (3) pp. 13-21.

[14] M. Ludlum - W. Xu - V. Ramachandran - J. Teeman (2015) Maturity, Gender, Parenthood and Ethical Orientation: A Three Campus Survey. Mustang Journal of Business and Ethics, 6 pp. 6778.

[15] M. Ludlum - S. Moskaloinov (2009) Identifying Russia's Corruption Problem: A College Student Survey. Procedings of the Academy for Studies in International Business, 9 (9) pp. 17-21.

[16] K. A. Lozier (2012) Student Perceptions of Academic Dishonesty Scenarios, Honors Thesis, Ball State University. megtekinthető: http://cardinalscholar.bsu.edu/handle/123456789/195858, letöltés dátuma: 2016. március 12.

[17] E. Barizsné Hadházi - Zs. Kiss (2017) Egyetemi hallgatók etikai attitúdjei a csalással kapcsolatban. Taylor: Gazdálkodás- és Szervezéstudományi Folyóirat: Virtuális Intézet KözépEurópa Kutatására Közleményei, 9 (1) pp. 121-129.

[18] D. L. Paulhus - K. M. Williams (2002) The Dark Triad of personality: Narcissism, Machiavellianism, and psychopathy. Journal of Research in Personality, 36 (6) pp. 556-563.

[19] T. A. Judge - J. A. LePine - B. L. Rich (2006) Loving Yourself Abundantly: Relationship of the Narcissistic Personality to Self- and Other Perceptions of Workplace Deviance, Leadership, and Task and Contextual Performance. Journal of Applied Psychology, 91 (4) pp. 762-776.

[20] R. Raskin - C. S. Hall (1981) The narcissistic personality inventory: Alternate form reliability and further evidence of construct validity. Journal of Personality Assessment, 45 (2) pp. 159-162.

[21] R. Christie - F. Geis (1970) Studies in Machiavellianism. Academic Press, New York.

[22] M. R. Levenson - K. A. Kiehl - C. M. Fitzpatrick (1995) Assessing psychopathic attributes in a noninstitutionalized population. Journal of Personality and Social Psychology, 68 (1) pp. 151158.

[23] R. D. Hare - C. S. Neumann (2009) Psychopathy: Assessment and forensic implications. Canadian Journal of Psychiatry, 54 (12) pp. 791-802.

[24] P. K. Jonason - G. D. Webster - D. P. Schmitt - N. P. Li - L. Crysel (2012) The Antihero in Popular Culture: Life History Theory and the Dark Triad Personality Traits. Review of General Psychology, American Psychological Association, 16 (2) pp. 192-199.

[25] E. H. O’Boyle, Jr. - D. R. Forsyth - G. C. Banks G. C, - M. A. McDaniel (2012) A Meta-Analysis of the Dark Triad and Work Behavior: A Social Exchange Perspective. Journal of Applied Psychology, American Psychological Association, 97 (3) pp. 557-579.

[26] P. K. Jonason - S. B. Kaufman - G. D. Webster - G. Geher (2013) What Lies Beneath the Dark Triad Dirty Dozen: Varied Relations with the Big Five. Individual Differences Research, 11 (2) pp. 81-90. 